\title{
An Analysis of Slang Words in Star Wars Jedi Academy: The Force Oversleep
}

\author{
Debora Natalia Hutabarat, Roma Ayuni Lubis, Yulianus Harefa \\ University of Sumatera Utara \\ hutabaratdebora425@gmail.com
}

\begin{abstract}
This thesis is study about the types and the meaning of each slang words in Star Wars Jedi Academy: The Force Oversleep. The theory supported this analysis is Eric Partridge theory (2004) explain about types of slang words. This thesis is designed as library research, the methodology used in this thesis is qualitative description method. The data contained in this thesis is taken from the words which contained in slang words in Star Wars Jedi Academy: The Force Oversleep storybook, the data is taken from whole pages, start from page 6 until page 172. The result of this analysis found 2 types of slang words, (1) Public School and University, the students become the main source in this type of slang, and (2) Society Slang, which is commonly used in daily conversation and connected to the society. Then, the researcher explained the meaning of each slang words based on context.
\end{abstract}

Keywords: Sociolinguistics; slang, types of slang; Eric Partridge, storybook.

\section{Intisari}

Skripsi ini adalah kajian tentang jenis-jenis dan makna dari setiap kata-kata slang dalam Star Wars Jedi Academy: The Force Oversleep. Teori yang mendukung kajian ini adalah teori yang dikemukakan oleh Eric Partrige (2004), yang menjelaskan tipe-tipe kata-kata slang. Penelitian ini merupakan penelitian kepustakaan, yang menggunakan metode deskriptif kualitatif. Data yang terdapat dalam kajian ini diambil dari kata-kata yang terdapat dalam buku cerita Star Wars Jedi Academy: The Force Oversleep, data diambil dari keseluruhan buku, dimulai dari halaman 6 hingga halaman 172. Dalam kajian ini ditemukan dua jenis kata slang yaitu, (1) Public School and University, murid-murid menjadi sumber utama dalam jenis slang ini, dan (2) Society Slang, dimana biasa digunakan dalam percakapan sehari-hari dan hubungan dengan masyarakat. Penulis menjelaskan arti dari setiap kata-kata slang berdasarkan konteks. Kata Kunci: Sosiolinguistik; slang; jenis-jenis slang; Eric Partridge; buku cerita.

\section{Introduction}

Language variety in the basic concept of sociolinguistics is a variety of languages consisting of formal and informal languages. In formal situation, language that is used is called standard language while language variety that is used in informal situation is called non-standard language. The characteristic in formal language is more complete and complex using proper 
grammar and standard vocabulary, this variation is usually used in state speeches, official meetings, official correspondence, textbooks, papers, scientific papers, etc.

Meanwhile the non-standard language that is usually used in informal situation does not fulfill any standard norms, not conforming in grammar, pronunciation, and etc. This variety is a variation that is commonly used in informal situations such as talking with family while on vacation, sports, recreation, and so on. One example of non-standard language is slang. Slang is the language that most often used and slang language nowadays like daily language in life. Recently slang is also used commonly by teenagers not only used by certain communities as secret expressions, teenagers use slang in their daily communication in their community or environment. Slang words are frequently used in community as well, included the books. Nowadays, adult and young certainly read a book, it does not matter what book it is. The use of slang words in the book due to many things, starts with the characterization of the book itself, in order to the readers do not feel bored and too rigid.

However, not all readers could understand about the slang words which found in the book, and according to (Leech 1981; Svartvik 1981;) slang is not usually understood by people outside a particular social group, and so has value in showing the intimacy of its member. And due to these facts, the researcher is interested in doing a research to analyze the slang words in Star Wars Jedi Academy: The Force Oversleep and will discuss about how slang words are found in this book, in order to the readers can be informed how slang words are identified and can understand about their meanings.

In this research, the source of data is a storybook entitled Star Wars Jedi Academy: The Force Oversleep which written by Jarret J. Krosoczka 2017 and published by Scholastic Inc. The data taken from whole pages, page 6 until page 172 and the data are the dialogue between the characters which used in this storybook. Star Wars Jedi Academy: The Force Oversleep is a title in the Star Wars Jedi Academy series. The characters contained in this storybook are Victor, Christina, Maya, Cole, Artemis, Emmett, Elara, Zavyer, Ms. Catara, Victor's Mother, Russell, Master Yoda, and Krio Vin.

This storybook is told about life at a Jedi Academy which Victor as a main character, in an academic life in a galaxy far, far away. When Victor returned to the academy but everything 
was not as he planned, because a new student at the academy got the drama lead roles that Victor wants, and also Master Yoda is always angry at Victor because Victor always keep oversleeping. Victor felt everything was hard for year two.

This research analyzed the types of slang words by using a theory proposed by (Eric Partridge 2004) about type of slang words to identify the types of slang in Star Wars Jedi Academy: The Force Oversleep. The state of the art of this research is taken from some related journals on slang words as a guide or examples of research being carried out at this time:

1. Bob Krisdianka, 2019. In his thesis AN ANALYSIS OF SLANG WORDS USED IN BLACK PANTHER MOVIE described one by one words of slang that found from the object, which is the similarity between with this research while the difference is his thesis used a movie for his object while this research is used a storybook.

2. Muzayyanah, 2015. The similarity between her research and this thesis are both using fiction book. In her thesis analyzed only the slang words, her thesis entitled $A$ DESCRIPTION OF SLANG TRANSLATION IN THE DIARY OF A WIMPY KID NOVEL. But she used Maxwell qualitative research emphasis on description words rather than number.

3. Winda Pradianti, 2013. Her thesis entitled THE USE OF SLANG WORDS AMONG JUNIOR HIGH SCHOOL STUDENTS IN EVERYDAY CONVERSATION aims to investigate slang words used by ninth grade students. The similarity between her thesis and this research is analyze the use of slang words and types of slang words, although her thesis is used questionnaires and interview to collected the data and the data were calculated in terms of frequency presented in tables and chart, and it be the differences with this research.

\section{Research Method}

This research used a qualitative research. Qualitative research is well suited for understanding phenomena within their context, uncovering links among concepts and behaviors, and generating and refining theory (Miles 2014; Huberman 2014; Saldana 2014). The reason why the researcher chose this method to analyze the data because it is more suitable with the data, which is Star Wars Jedi Academy: The Force Oversleep does not a numerical or counting 
process when analyzed it. The source of data is a storybook entitled Star Wars Jedi Academy: The Force Oversleep which written by Jarret J. Krosoczka 2017 and published by Scholastic Inc. The data taken from whole pages, page 6 until page 172 and the data are the dialogue between the characters which used in this storybook. According (Miles 2014; Huberman 2014; Saldana 2014); data collection is divided into 4 types, those are observation, questionnaire, interview, and study of document. Steps in collecting the data were as follow: reading the storybook Star Wars Jedi Academy: The Force Oversleep in order to get the slang words used in this storybook, analyzing which dialogue that contains of slang words, observing and mark the words included in slang words. The data of this research were analyzed using these following steps according to Miles and Huberman, which divide the steps in data analysis with several parts. That is data collection, data reduction, data display, and conclusion. And steps in that are used in analyzed this research were as follow: writing down the marked slang words on Star Wars Jedi Academy: The Force Oversleep, classifying and identifying the types of slang words on Star Wars Jedi Academy: The Force Oversleep accordance with Eric Partridge theory about types of slang, describing how slang words are meant in Star Wars Jedi Academy: The Force Oversleep.

\section{Result and Discussion}

\section{Result}

The researcher found there are 15 slang words found in Star Wars Jedi Academy: The Force Oversleep, which can be further and categorized according to Eric Partridge's theory, it will be given as follow:

Table 1.Types, Meaning, and Word Classes of Slang Words in Star Wars Jedi Academy:

\section{The Force Oversleep}

\begin{tabular}{|l|l|l|l|l|}
\hline No & Sentence & Types of Slang & Meaning & Word Class \\
\hline 1 & Vacation with my bestie! & Public House & Best friend & Noun \\
\hline 2 & Good night, study buddy & Public House & $\begin{array}{l}\text { Nickname for a } \\
\text { friend }\end{array}$ & Noun \\
\hline 3 & Lemme see & Society Slang & Let me see & Verb \\
\hline 4 & Sup, Cole? & Society Slang & What's up? & Interjection \\
\hline
\end{tabular}




\begin{tabular}{|c|c|c|c|c|}
\hline 5 & Yup. You've guessed it & Society Slang & Yes & Noun \\
\hline 6 & $\begin{array}{l}\text { Hi, Victor! Whatcha } \\
\text { doing? }\end{array}$ & Society Slang & What are you? & Pronoun \\
\hline 7 & $\begin{array}{l}\text { So, you know that she } \\
\text { has a crush on you, } \\
\text { right? }\end{array}$ & Society Slang & $\begin{array}{l}\text { A someone you } \\
\text { liked or you } \\
\text { loved }\end{array}$ & Noun \\
\hline 8 & I can't even deal & Society Slang & Overwhelmed & Verb \\
\hline 9 & 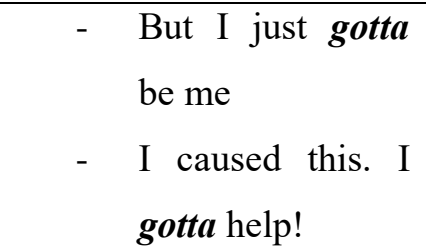 & Society Slang & Got to & Verb \\
\hline 10 & Oh Em Gee! & Society Slang & Oh My God! & Interjection \\
\hline 11 & I probably flunked & Society Slang & Failed & Verb \\
\hline 12 & $\begin{array}{ll}- & \text { C'mon } \\
- & \text { C'mon } \mathrm{Vic!} \\
- & \text { C'mon, sis. }\end{array}$ & Society Slang & Come on & Adjective \\
\hline 13 & Kinda, Ok after all & Society Slang & Kind of & Adverb \\
\hline 14 & $\begin{array}{l}\text { Gonna miss the } \\
\text { bunkmates! }\end{array}$ & Society Slang & Going to & Verb \\
\hline 15 & $\begin{array}{l}\text { A Jedi musta clear their } \\
\text { minds. }\end{array}$ & Society Slang & Must have & Verb \\
\hline
\end{tabular}

\section{Discussion}

This section discusses the types of slang words and how slang words are meant in this research. The data taken from whole pages, page 6 until page 172 and the data are the dialogue between the characters which used in this storybook. The analysis in this thesis is explained and proven with urbandictionary.com and the types of slang words are analyzed and categorized according to Eric Partridge. Based on the data in this research, the researcher found that there are 15 slang words found in it, and 2 types of slang words identified that according to Eric Partridge theory, there are:

1) Public school and university 
2) Society slang

First, public school and university slang shows a genial, cheery, materialistic but not gross or cynical, (Eric Partridge 1933). Then the researcher found out two words of slang that are categorized as public school and university slang such as Bestie, Buddy because the suitability of the characteristics of the public house slang and their nature of words are not gross or cynical.

Second, society slang shows a joyously or jauntily over the object and the practices of the slang user, like (Eric Partridge 1933) "Society slang is concerned the spirit of universe, the world life it also hovers, joyously or jauntily over object and the practices of the slang user's own calling with the difference jargon treats the solemnity and respect the avocation it serves, but slang seldom retains respect toward it, treats that avocation with the detached amusement that, viewed from a far, every human activity seems to invite."

The researcher conclude that the society slang such as a familiar and common words that comes from society and sometimes even it has rude meaning, it still commonly used in daily conversation in society of human being, because it easy to speak and easy to change based on era and trend in society. Then, the researcher found out there are 13 slang words of society slang in Star Wars Jedi Academy: The Force Oversleep based on Eric Partridge's theory, such as Lemme see, Sup?, Whatcha?, Oh Em Gee!, Gonna, Gotta, C'mon, I can't even, Kinda, Musta, Yup, Crush, Flunk.

In this research, the researcher found out the meaning of slang words that found in Star Wars Jedi Academy: The Force Oversleep, and below are some analysis results that have been analyzed by the researcher, as follow:

\section{1) Bestie}

The word bestie found in page 11, the word appeared by Cole when he posted his picture with his best friend, he posted it on his social media like Elara did before. He posted with caption "Vacation with my bestie!" and showed below: 


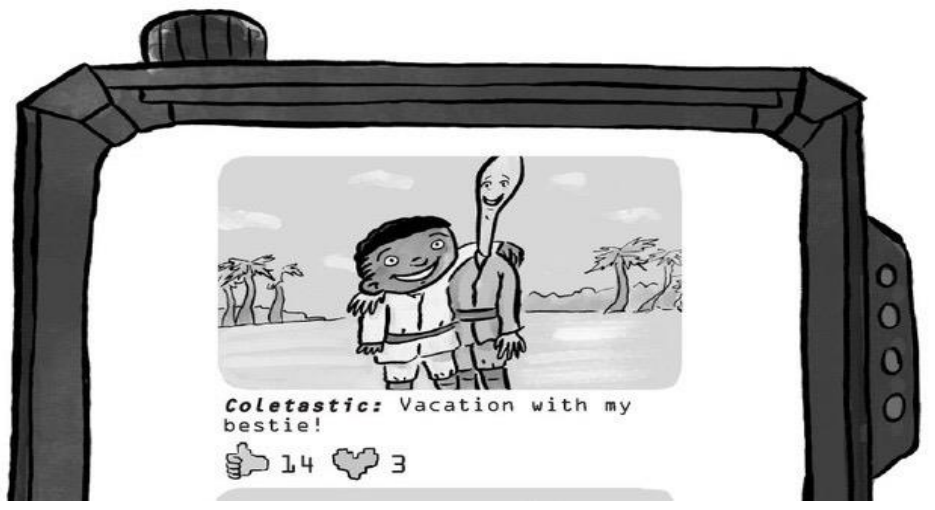

This picture posted by Cole after he did his vacation with his best friend, Emmett, and hence based on this context the meaning of bestie is best friend. Below is an explanation and evidence from the context above that has been captured from urbandictionary.com:

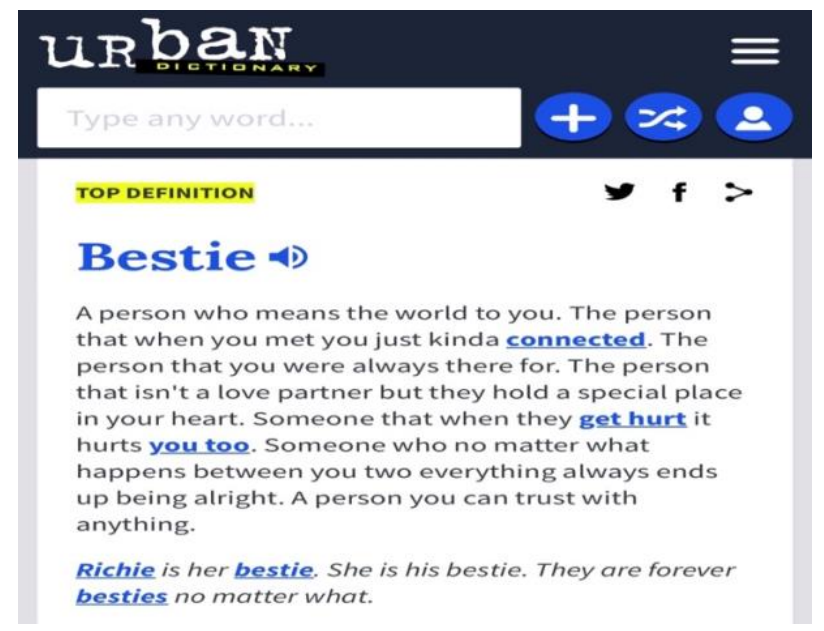

\section{2) Buddy}

The word buddy found in page 119. The word appeared by Elara who is Victor Starspeeder's friend, the main character. She posted a photo of Victor sleeping in her social media, with quote "Good night, study buddy. \#too cute" and showed below: 


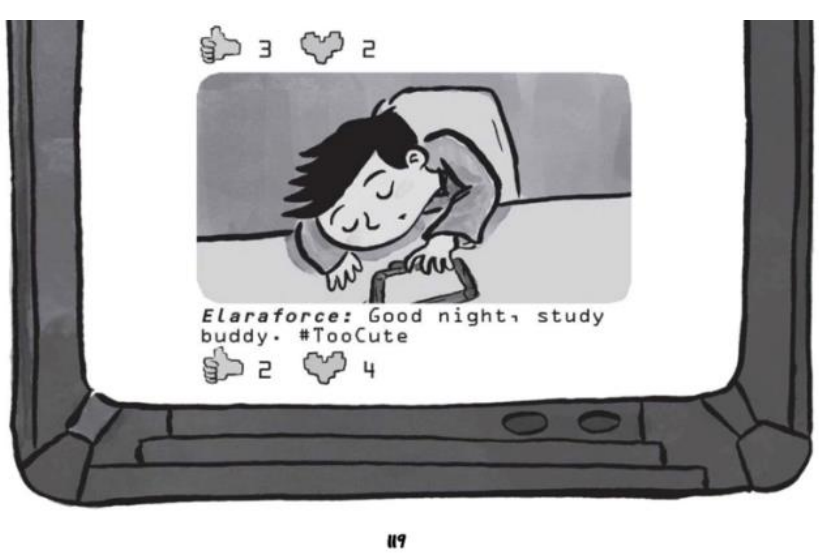

From the quotation above, the meaning of buddy is a friend or as a nickname for a friend. Below is an explanation and evidence from the context above that has been captured.

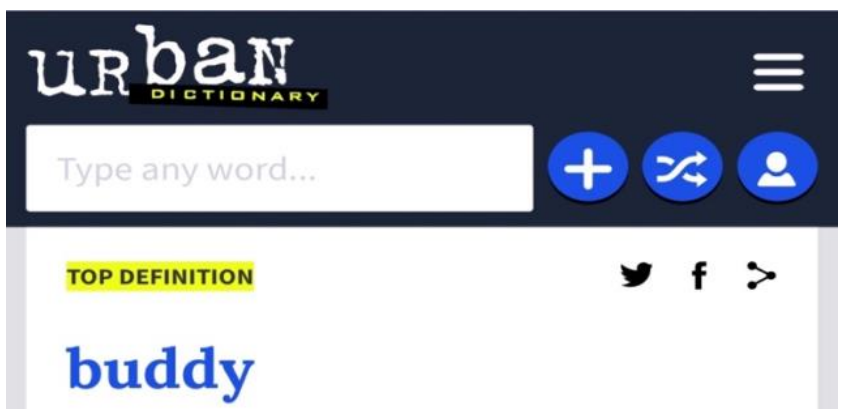

a condescending, demeaning nickname guys use for other guys they pity or feel more influential over.

3) Lemme see

The word lemme see found on page 24, the dialogue happened between Victor and Zavyer at school, when Victor first met with Zavyer, the new student in the academy. Showed below: 


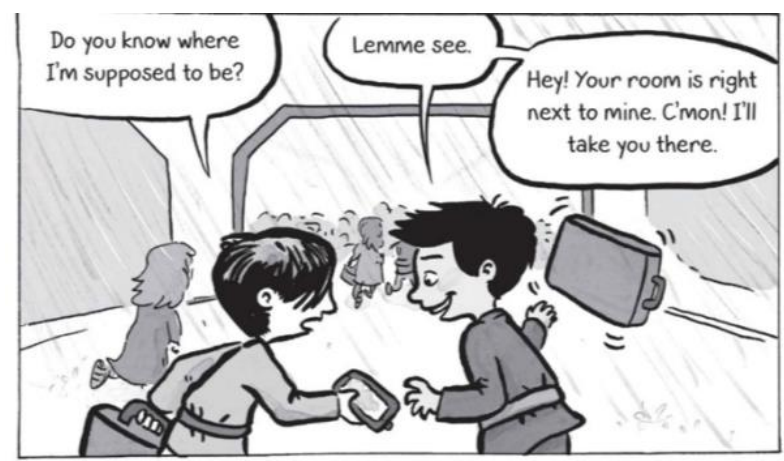

24

From the conversation above, the meaning of lemme see is let me see. Victor wants to help Zavyer to show where Zavyer's room. Below is an explanation and evidence from the context above that has been captured.

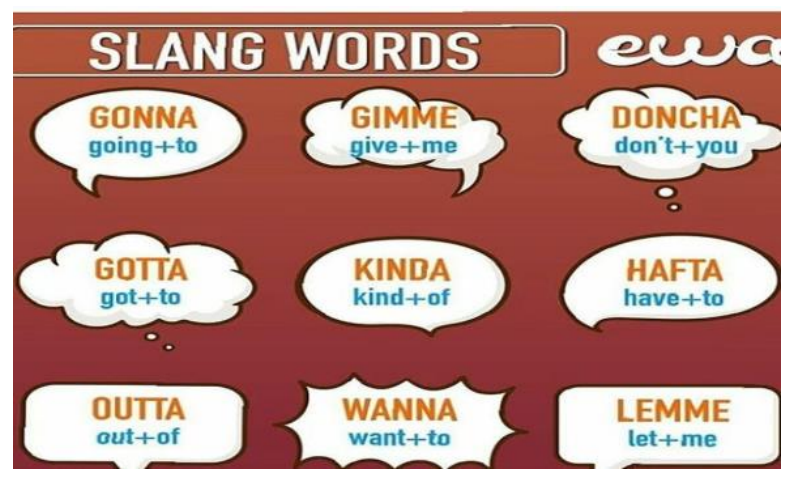

4) Sup?

The word sup? found on page 26 between Cole and Zavyer when Cole asked for news about Zavyer after a long time no see. Showed below:
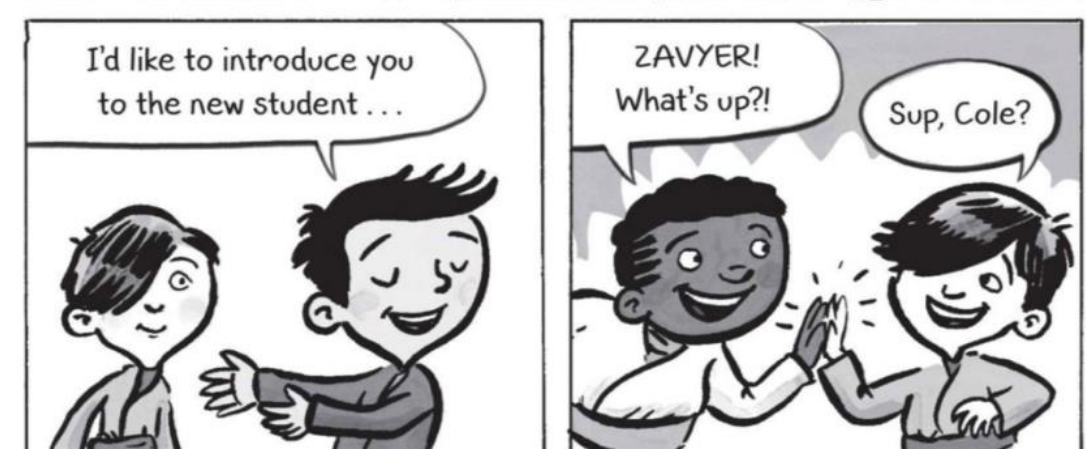
The word sup? appeared from Cole when he met Zavyer and asking for Zavyer's condition. Whereas at first, Victor wanted to introduce Zavyer to Cole, because Zavyer was a new student at the academy, but Cole already known Zavyer and he asked how Zavyer was. The meaning of sup? is what's up. Below is an explanation and evidence from the context above that has been captured.

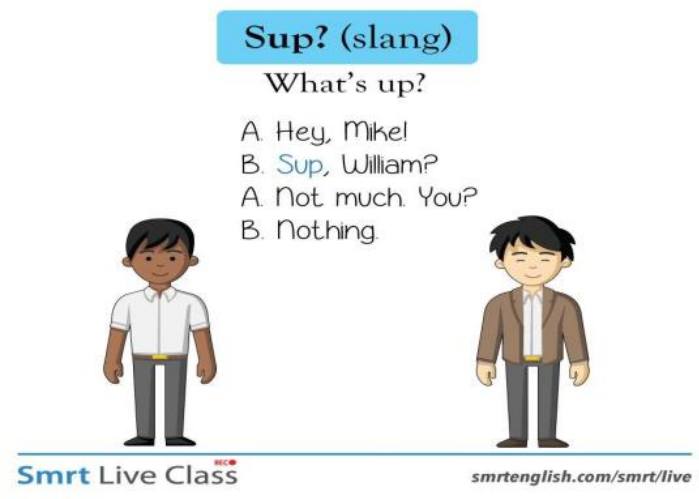

5) Yup

The word yup found on page 43 when Victor, the main character, wrote about his diary of the day, about what the he had faced and what he feels. Showed below:

department. So who did get the lead you ask? Yup. You've guessed it. . . the new kid, Zavyer. I think that the entire galaxy is conspiring against me. I

The word yup used by victor in his diary book, and the meaning of yup is yes. Below is an explanation and evidence from the context above that has been captured. 


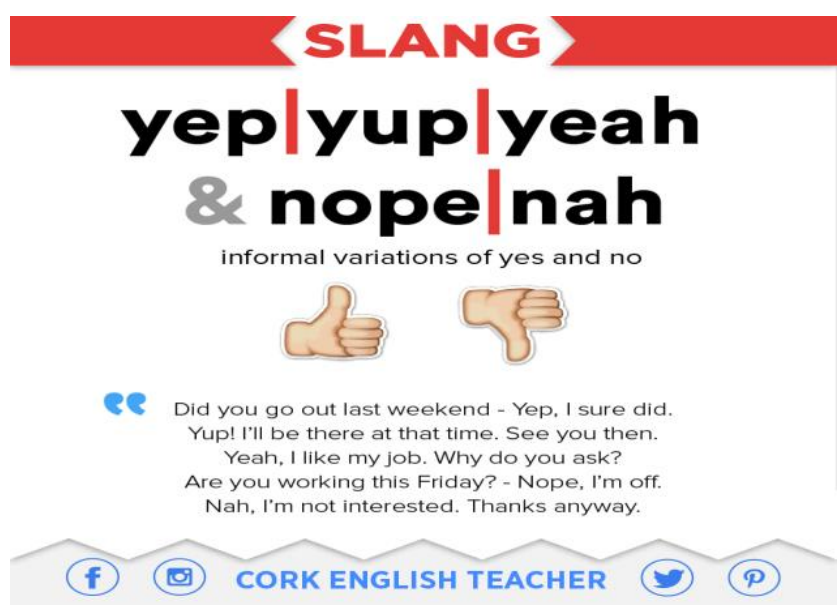

\section{Conclusion}

The researcher would like to present the conclusion and were started as follow:

1) There are two types of slang words that found in Star Wars Jedi Academy: The Force Oversleep:

a) Public school and university slang. Public school and university slang told about the word that is used by their communities and nor cynical. The writer found (2) two of slang words which categorized as public school slang in this storybook, they are:

\section{Buddy, Bestie.}

b) Society slang. Society slang is commonly used daily speaking or conversation and connected to the society. The writer found (13) thirteen of slang words which categorize as society slang in this storybook, they are: Lemme see, Sup?, Yup, Whatcha, Crush, I can't even, Oh Em Gee!, Gotta, Flunk, C'mon, Kinda, , Gonna, Musta.

2) The meaning of slang words in Star Wars Jedi Academy: The Force Oversleep based on type of slang words that used and background of the characters and setting of the dialogue scene. From the explanation before, the researcher concluded the meaning of each slang words based on context and assisted by explanations from urbandictionary.com

\section{References}

Chaer, A and Agustina, L. 1995. Sosiolinguistik. Jakarta: Rhineka Cipta.

Creswell. J. W. 2010. Research Design: Pendekatan Kualitatif, Kuantitaif, dan Mixed. Yogyakarta: PT. Pustaka Belajar 
Ekawati, L. 2018. Slang in Fast and Furious 7 Movie. Jambi: Universtitas Islam Negeri.

Latifah, S. N. 2017. An Analysis of Slang Words in Deadpool Movie. Mataram: Mataram University.

Lubis, I. D. 2018. A Study of Characteristic of Gay Slang Used In "Ada Si Manis di Jembatan". Medan: Universitas Sumatera Utara.

Mahmunik, S.N. 2015. An Analysis of Slang Language in Song Lyrics Used By Justin Bieber. Malang: Universitas Sunan Ampel.

Mutiara, S. 2017. An Analysis of Taboo Words in RnB Songs in Pitbull's Album "Globalization". Indonesia: Universitas Sumatera Utara.

Muzayyanah. 2015. A Description of Slang Translation in the Diary of a Wimpy Kid Novel. Semarang: English Language Education Universitas Islam Negeri Walisongo.

Nababan, P. W. J. 1993. Sosiolinguistik: Suatu Pengantar. Jakarta: PT. Gramedia.

Partridge, E. 1933. Slang Today and Yesterday. New York: William Press.

Prasetiaji, D. 2015. Analisis Bahasa Gaul Pada Novel Kambing Jantan Karya Raditya Dika. Surakarta: Program Studi Magister Pengkajian Bahasa, Sekolah Pascasarjana, Universitas Muhammadiyah Surakarta.

Spolsky, B. 1998. Sociolinguistics. Oxford: Oxford University Press.

Sutopo, H. B. 2002. Metode Penelitian Kualitatif. Solo: Universitas Sebelas Maret Press.

$\mathrm{http} / /$ www.starwars.com/2017/news/jarret-j.krosoczka/ accessed in (November 2019).

http//www.byucbmr.com/2018/review/star-wars-jedi-academy/ accessed in (November 2019).

http//www.starwarsfandom.com/ 2017/news/jarret-j/ accessed in (November 2019).

\section{Appendices}
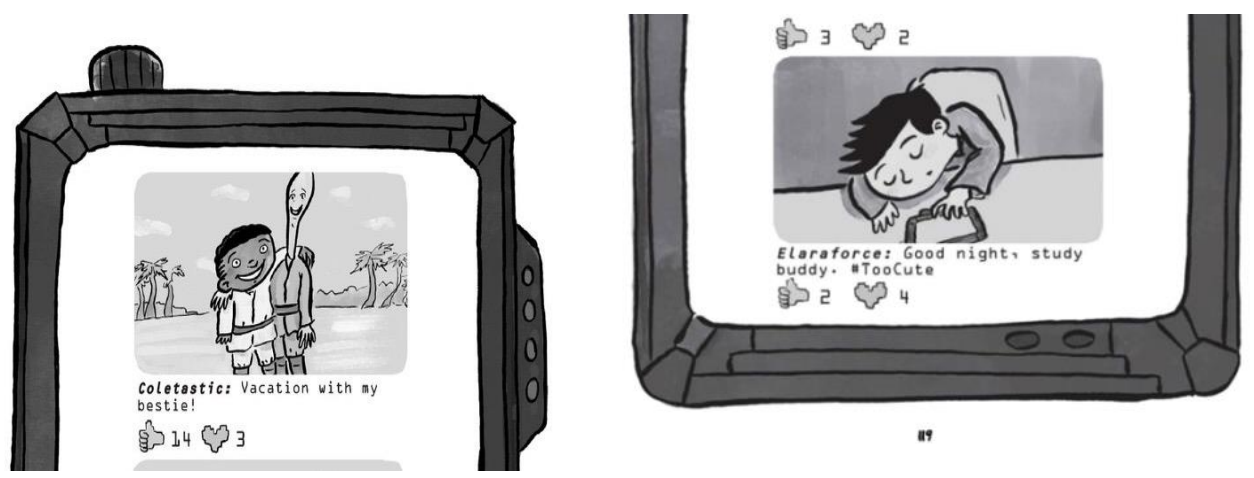
Debora Natalia Hutabarat dkk, An Analysis of Slang Words in Star Wars Jedi Academy: The Force Oversleep

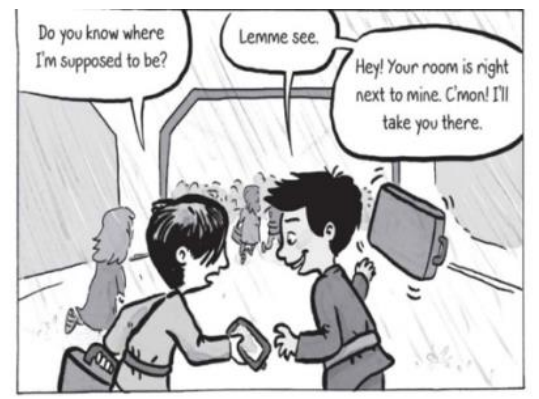

24

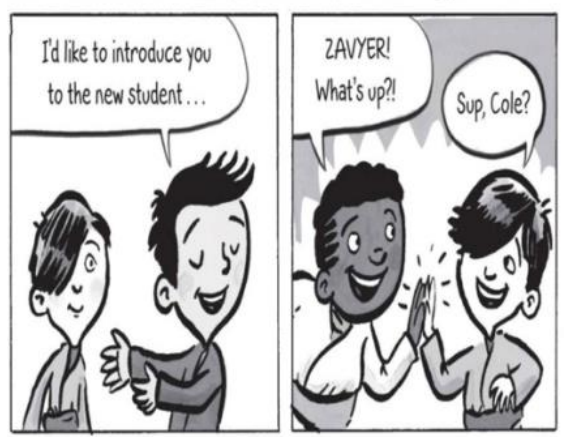

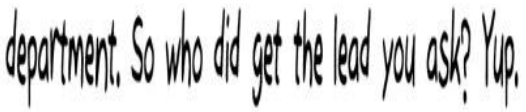

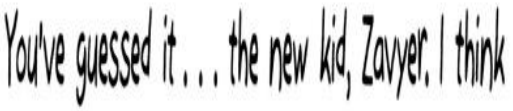

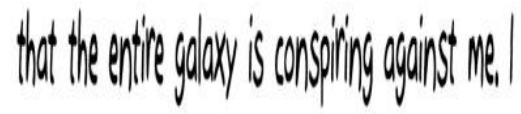
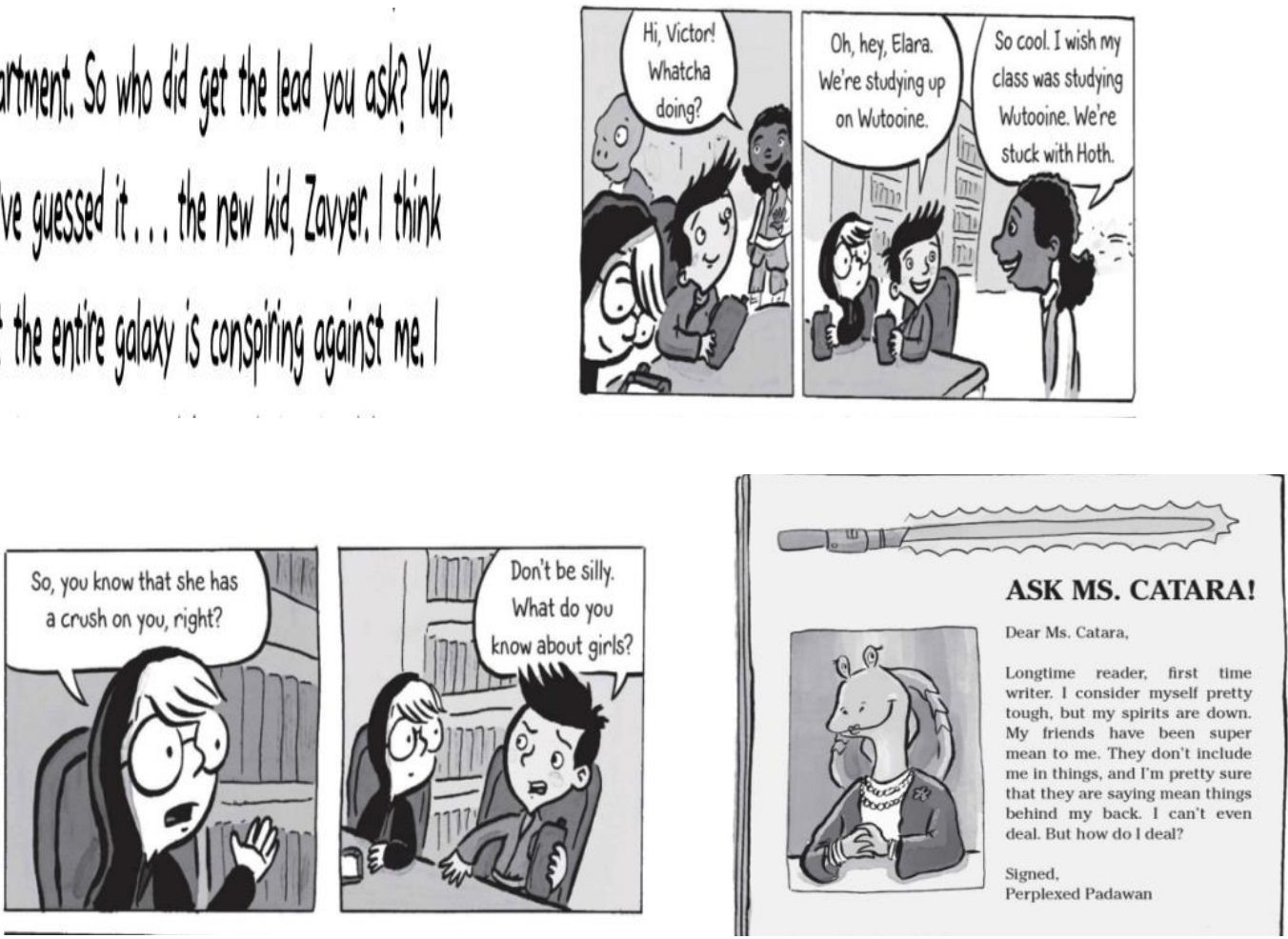
Debora Natalia Hutabarat dkk, An Analysis of Slang Words in Star Wars Jedi Academy: The Force Oversleep
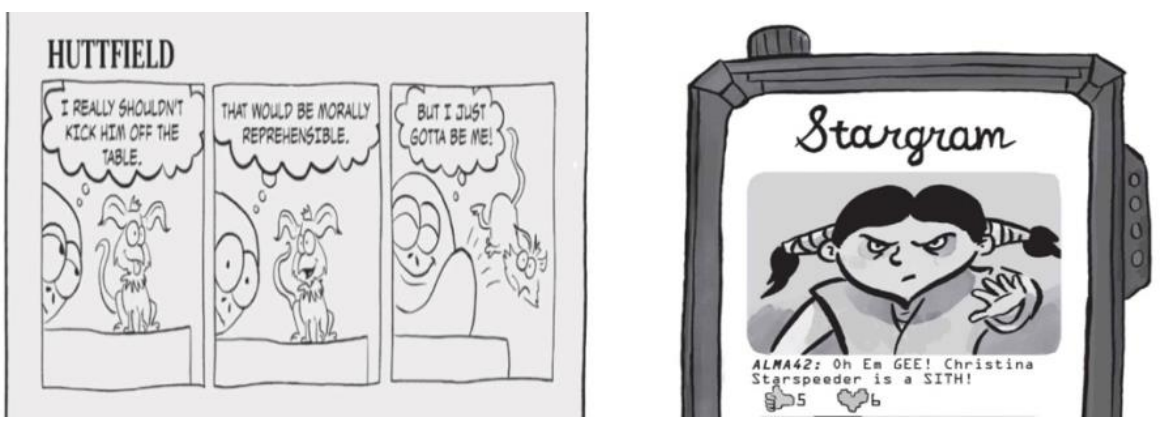

me a detention. He did make me take the tesst that same day, so I still didon't get to study, Unless my guesses were spot-on, I probady flunked.
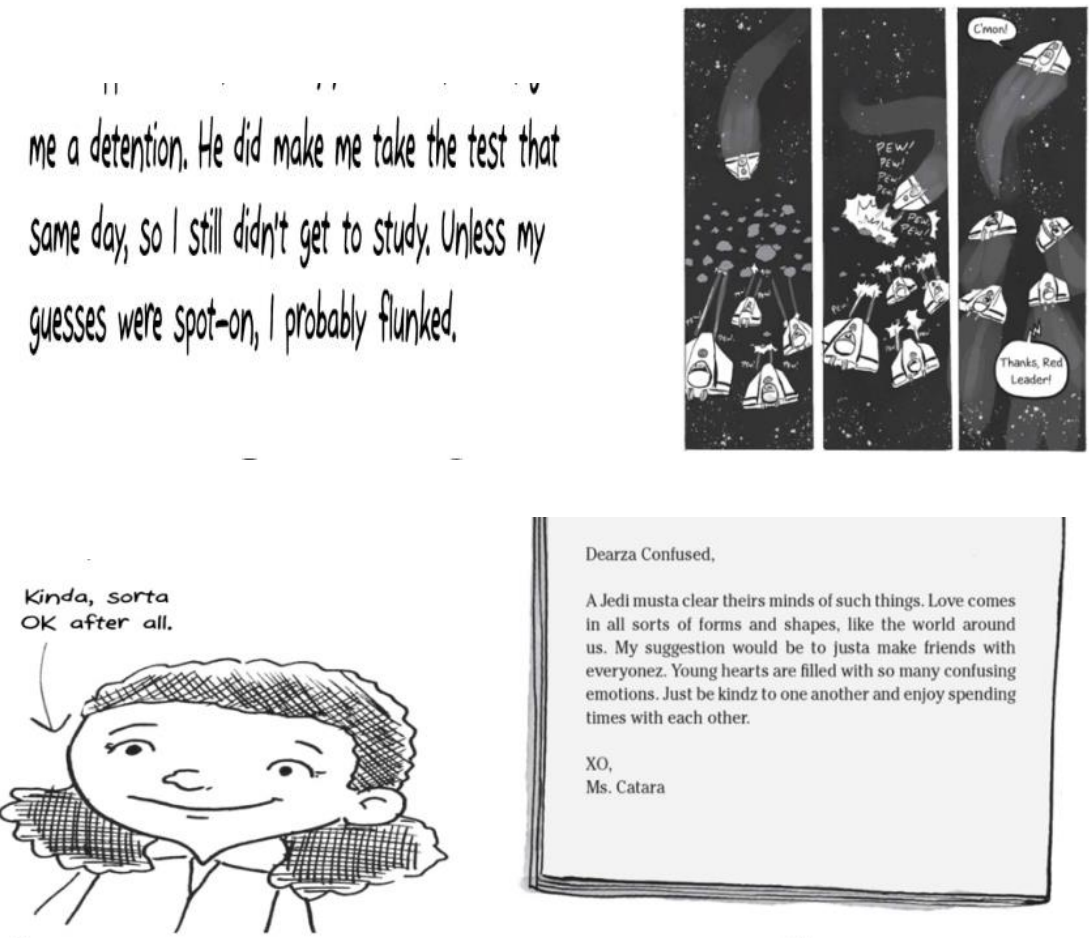

131
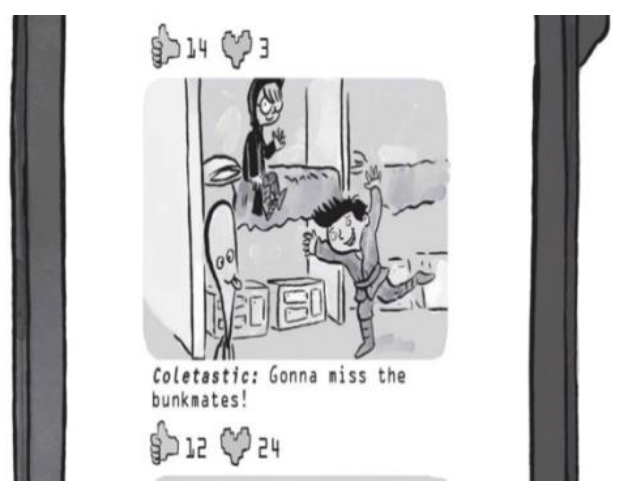